\title{
Evidence of historical seismicity and volcanism in the Armenian Highland (from Armenian and other sources)
}

\author{
Arkady Karakhanian and Yelena Abgaryan \\ GEORISK Scientific Research Company, Yerevan, Armenia
}

\begin{abstract}
This work presents a summary on the development of studies of historical earthquakes in Armenia and adjacent parts of Turkey and Iran. Since ancient times, this region has been an arena where active geodynamic and seismic history intermingled with no less active and dynamic evolution of human cultures and societies. A long-term historical record in this region beginning as early as the 8th century B.C. provides abundant evidence that can make an inestimable contribution to studies of historical seismicity and volcanism in the area. We discuss the main research methodology and sources used, and dwell on the principal catalogues of historical earthquakes compiled to date.
\end{abstract}

Key words Armenia - historical seismicity - volcanism - catalogue

\section{Introduction}

The volcanic uplands of the Armenian Highland are situated between the Anatolian Plateau and the Iranian Plateau and include areas of today's Armenia, Eastern Turkey, Southern Georgia, Western Azerbaijan and Northwestern Iran (fig. 1) (Abich, 1882; Mutafian, 1988; Hewsen, 2001).

The Armenian Highland falls in the central part of the zone of continental collision of the Arabian lithosphere plate (Jackson and McKenzie, 1988; Dewey et al., 1986; Taymaz et al., 1991; Jackson, 1992; Jackson and Ambraseys, 1997).

The North-Anatolian Fault, East-Anatolian Fault, Levant Fault, Zagros Fault and other ac-

Mailing address: Dr. Arkady Karakhanian, GEORISK Scientific Research Company, 24a Marshal Baghramian Ave. 375019 Yerevan, Armenia; e-mail: georisk@sci.am tive faults cut across the Armenian Highland. Many strong earthquakes of $M=7.0-7.7$ are associated with these faults (Ambraseys and Melville, 1982; Jackson and McKenzie, 1988; Ambraseys and Jackson, 1998).

Clear estimates of maximum potential magnitudes and earthquake recurrence intervals for the Armenian Highland are lacking.

The recorded parameters of recent strong earthquakes in the region determined unexpectedly large scales of destruction and high casualty rates, which later forced re-estimation of the seismic hazard level. Among such strong earthquakes we can mention the Chaldiran earthquake in $1976(M=7.1)$, Norman earthquake in $1983(M=7.0)$, and Bingel earthquake in $2003(M=6.4)$ in Eastern Turkey, Spitak earthquake in $1988(M=7.1)$ in Armenia, Roudbar earthquake $(M=7.7)$ in Iran, and Racha earthquake in $1991(M=7.1)$ in Georgia.

Collection of data and compilation of as much complete database on historical and prehistorical seismicity as possible represents one of the most important tasks to be addressed in seismic hazard assessment. 


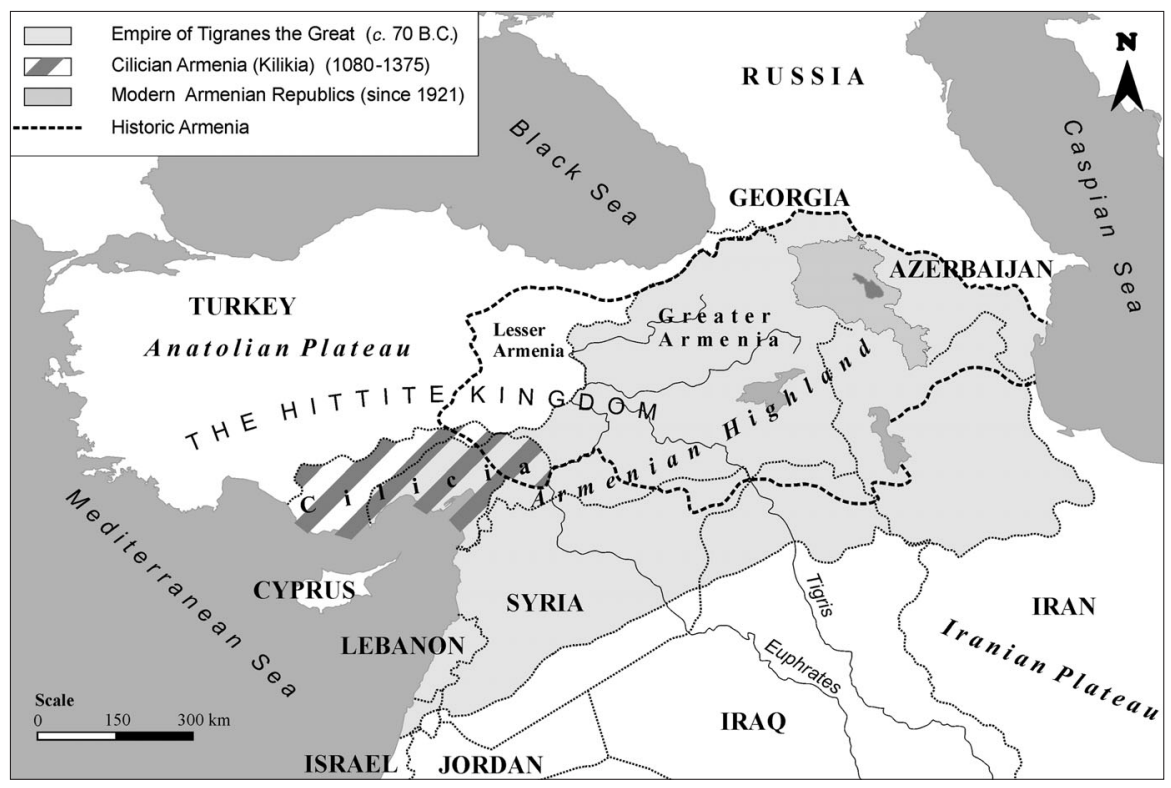

Fig. 1. The area of the Anatolian semi-island in the Armenian Highland with historical Hittite and Armenian kingdoms from the 18th century B.C. till the 14th century A.D. (from Hewsen, 2002)

Considering high rates of recent deformation in the centre of the Arabian collision zone, the recorded manifestations of seismic activity in the 20th century may be insufficiently representative for a reliable estimation of the hazard. There is a bulk of historical and paleoseismological evidence indicating that many strong earthquakes occurred in this area in the past (Stepanian, 1964; Ambraseys, 1975, 1988; Ambraseys and Melville, 1982; Ambraseys and Adams, 1989; Bommer and Ambraseys, 1989; Berberian, 1994, 1997; Guidoboni and Traina, 1995; Guidoboni et al., 1996; Shebalin et al., 1997; Philip et al., 2001; Karakhanian et al., 1997, 2002, 2003).

From the 1 st century B.C. till the 14th century A.D., the Armenian Highland was the land of historical Armenian kingdoms (fig. 1) (Mutafian, 1988; Armenie, 1996; Hewsen, 2001). After the failure of the last Armenian Kingdom, between the 14th and 19th centuries A.D., the Armenian Highland continued to be the centre of culture and activity of a large Armenian population. The centres of Armenian culture and
Christian monasteries in particular, have preserved plenty of recorded evidence on natural catastrophes that occurred in these areas during more than 1500 years. Hittite, Urartian, Greek, Persian, Arab and Turkish sources supplement the scenes of history of seismic and volcanic activity in the Armenian Highland.

The main purpose of this work is to consider and analyze the present condition of studies of new historical evidence on natural disasters in the Armenian Highland.

\section{Sources}

Most existing data on historical strong earthquakes in the Armenian Highland are derived from the analysis of written sources, among which Armenian manuscripts and ecclesiastical materials include the largest share of information. Monk chroniclers and historians provided detailed descriptions of many natural disasters in Armenia, Anatolia, Syria, Levant, 
Western Iran and Southern Caucasus from the 5 th century to the 19th century A.D.

These chronicles are of unique value considering the abundance and level of detail in the references to natural phenomena they contain. The main part of these manuscripts (more than 20000 ) is kept in Matenadaran, the Institute of Ancient Manuscripts in Yerevan (Armenia), and about 9000 are in the archives of Jerusalem, Venice, Vienna, Nor Jougha (Iran), Lebanon and Paris. Earthquake catalogues include only part of data from sources in Armenia (Matenadaran) and in Venice (San Lazzaro). Recent studies have shown that manuscript sources of Matenadaran and the Armenian Apostolic Church archives may attest to earthquakes earlier unknown to scholars, or determine a substantial revision of parameters of already known events (Haroutunian et al., 1993; Haroutunian and Karakhanian, 1997; Karakhanian et al., 2002, 2003; Guidoboni et al., 2003).

In many respects, trustworthy interpretation of evidence from Armenian sources written in Old Armenian depends on how well scholars know this language, posing considerable difficulties for translation. Besides, the sources use the Armenian calendar, different from other systems of chronology, and a 12-h day scale, which also complicate the analysis.

Available written evidence on natural disasters in the Armenian Highland is not limited solely to the Armenian sources, but can be substantially added with information provided by Greek sources of the 5th century B.C. - 4th century A.D., Syrian of the 2nd-6th centuries A.D., Byzantine and Persian of the 3rd-15th centuries A.D., and Arab and Turkish for the 11th-19th centuries A.D. Moreover, important remarks can be extracted from notes of foreign travellers, who visited historical Armenia since the 12th century A.D. Use of evidence from various written sources allows cross-analysis and refining of earthquake-related data.

The earliest written records of volcanic and seismic catastrophes in the Armenian Highland were found in rock inscriptions of Hittite (the 26th and 18th centuries B.C.) and Urartian (8th century B.C.) kings (Ferraud, 1994; Karakhanian et al., 2002). A petroglyph dated to the 6th millennium B.C. with five pictures of volcanic eruption was found in the south of Lake Sevan (Karakhanian et al., 2002; Avagyan et al., 2003).

As archaeological and paleoseismological sources provide data on the early period events, not covered by written sources, they have been increasingly used in recent studies of seismic and volcanic catastrophes in the Armenian Highland (Philip and Karakhanian, 1999; Karakhanian et al., 2002; Avagyan et al., 2003). Despite the limited scope of information derived from this kind of source, they certainly have a future.

Archaeological data and radiocarbon age estimates enabled identification of strong earthquakes and volcanic eruptions occurred in the south of Armenia between 782 and 773 B.C., in the 18th century B.C., and in the 5th and 6th millennia B.C. (Philip and Karakhanian, 1999; Philip et al., 2001; Karakhanian et al., 2002). Paleoseismic data helped to record earthquakes of $M=7.2-7.4$ in the north and in the south of Armenia and date them to 400 B.C., 2200 B.C. and 7500 B.C., and estimate ages of 10 500, 20879 and 21705 years B.P. for other three earthquakes (Philip et al., 2001; Karakhanian et al., 2004).

New evidence on seismic disasters of the past can be derived from analysis of folklore sources. Nikonov (1991) and Berberian (1994) demonstrated that information in Armenian and Persian folk eposes can bear witness to earthquakes and volcanic eruptions. New folklore accounts from Armenian and Hittite eposes dated back to the 16th-12th and the 6th centuries B.C., respectively, are provided in Appendix A.

\section{Descriptive and parametric catalogues}

The history of collection and analysis of strong earthquake data from Armenian sources can be divided into several periods (table I). This division is rather conditional and based on both catalogue publication dates, and the objectives the compilers had to achieve. In Periods I and II, and at the early stage of Period III, catalogues reflected historical rather than seismological studies, while catalogues of the later two stages of Period III could serve databases for seismic hazard assessment We demarcate the boundary between the second and third stages in Period III at the occurrence of few 
strong earthquakes in the region during a short span (Spitak 1988; Roudbar 1990; Racha 1991; Erzinjan 1992), which aroused interest in seismic hazard assessment and compilation of earthquake catalogues.

Studying ancient manuscripts, L. Khanlaryan (1983) discovered a chronicle of Amiras Yerzncatsi (Amiras from Yerznca, a chronicler of the 17th century), who refers to strong earthquakes in his native town of Yerznca (an old Armenian name of the town of Erzinjan) (Chronicle of Amiras Yerzncatsi, 1988). Amiras entitled this chronicle The List of Earthquakes: it actually contains a list of earthquakes from 1045 to 1584 in chronological order with short notes describing the damage they caused. We consider this work of Amiras Yerzncatsi the earliest known attempt to collect strong earthquake data from Armenian sources and relate it to Period I (table I).

In general, the early period of collecting historical seismicity data from Armenian sources can be related to the works of Inčičean (1822, 1835), Shahatounianc' (1842), Alishan (1881, $1890)$ and Kostaneanc' (1902) in the 19th-early 20th centuries (Guidoboni and Traina 1995; Pirouzian et al., 1997). These authors were the first who integrated information about a large number of earthquakes, but never tried to estimate their parameters. The Earthquake Catalogue of the Russian Empire by Musketov and Orlov (1893) and studies of individual strong earthquakes by Abich (1862a,b; 1882) represent more detailed studies in the early period.

Table I included here, and detailed analysis by Guidoboni and Traina (1995) and Pirouzian et al. (1997), provide an idea of general trends of the later development of historical seismicity research. This work focuses on the most important points of historical seismicity studies undertaken in the region recently.

The fundamental descriptive catalogue of Stepanian published in 1964 was an important milestone in historical seismicity studies in Armenia. Stepanian's catalogue contains detailed information on more than thousand strong historical earthquakes that occurred since 550 B.C. till the early 20th century A.D. in Anatolia, Syria, Armenia, Georgia, Azerbaijan and Iran. In the meantime, this catalogue is mainly descrip- tive. Stepanian did not cite original sources of historical earthquake evidence, but just retold them liberally, without any critical analysis of the reliability of the data provided.

In 1977, The New Catalogue of Strong Earthquakes in the Territory of the USSR (Kondorskaya and Shebalin, 1977) presented the first estimates of principal parameters of strong historical earthquakes in the region of the Southern Caucasus republics of the USSR (Armenia, Georgia and Azerbaijan). The catalogue advised users to take into account the subjective character of information contained in historical sources, which, according to the authors of the catalogue, tended to exaggerate seismic hazard in the Caucasus, where strong earthquakes could not occur (Pirouzian, 1972; Borisov et. al., 1975; Kondorskaya and Shebalin, 1977; Borisov, 1982).

Later, the 1988 Spitak earthquake in Armenia and the 1991 Racha earthquake in Georgia, both with $M_{S}=7.1$, as well as the Roudbar earthquake of $1990(M=7.7$, NE Iran) and Erzinjan earthquake of 1992 ( $M=6.9$, E Turkey) proved that strong seismicity in the Armenian Highland, attested by the historical sources, was the case. After these events, studies of historical seismicity in the region gained strong impetus.

During the eight years from 1989 till 1997, 12 catalogues with historical seismicity data for Anatolia, Armenia, Caucasus and Iran were prepared and published (table I). Among them, 9 catalogues were parametric, and 3 were only descriptive. To date, the parametric catalogue of Shebalin and Tatevossian (1997) has been the most complete and representative one. The catalogue prepared for the Trans-Caucasian region by Berberian (1997) was the first attempt to summarize parameters estimated by different authors for the same earthquakes.

For historical seismicity analysis, of most interest are descriptive catalogues of Zeitounian (1991), Guidoboni and Traina (1995), and Guidoboni et al. (1996), based largely on Armenian sources. With its rich summary of historical accounts on strong earthquakes, Zeitounian's catalogue does not contain any comments or reliability analysis for the historical texts it presents. The catalogue itself has not been published yet. 


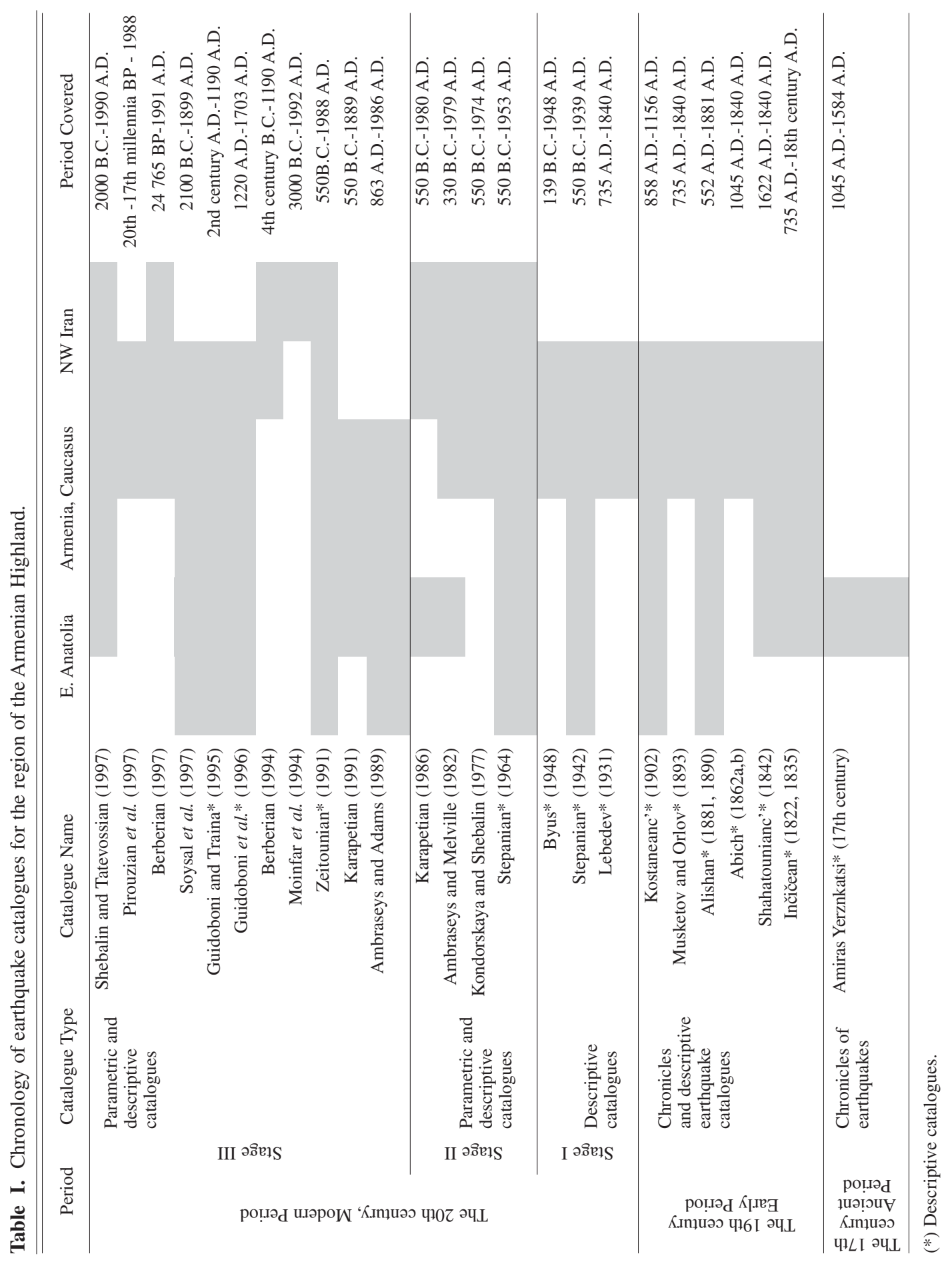


The first critical analysis of ancient Armenian manuscript texts, providing earthquake-related data, can be found in Guidoboni and Traina (1995), and Guidoboni et al. (1996). The authors identified cases of duplication and even triplication by historical seismicity catalogues of many seismic events (e.g., Dvin earthquakes of the 9th and 10th centuries), and revealed several false events and previously unknown strong earthquakes. The works of Zeitounian (1991), Guidoboni and Traina (1995), and Guidoboni et al. (1996) can be considered the next important milestone after the studies of Stepanian in 1964.

Unfortunately, the interest with respect to historical seismicity information has been declining in the region since 1997 and today studies in this field are episodic (Haroutunian and Karakhanian, 1997; Guidoboni et al., 2003). Less interest in seismic hazard problems fifteen years after the last disastrous earthquake in Ar- menia (Spitak, 1988) is explicable, but, along with general cuts of research financing today, it is one of the main reasons of the limited scope of historical seismicity studies in Armenia.

\section{Reappraisal of some earthquakes}

Our recent studies revealed some typical errors of the catalogues, and proved that certain data on historical earthquakes in the Armenian Highland can be complemented and corrected. Among frequent errors is the wrong identification of old geographic place-names reported by the sources, which considerably affects the accuracy of the catalogues.

Analyzing the report of Armenian chronicler Samuel Anetsi on the collapse of Mount Koghatu and resulting blockage of the Euphrates River in the earthquake of 802 A.D., Guidoboni and Traina (1995) locate the epicen-

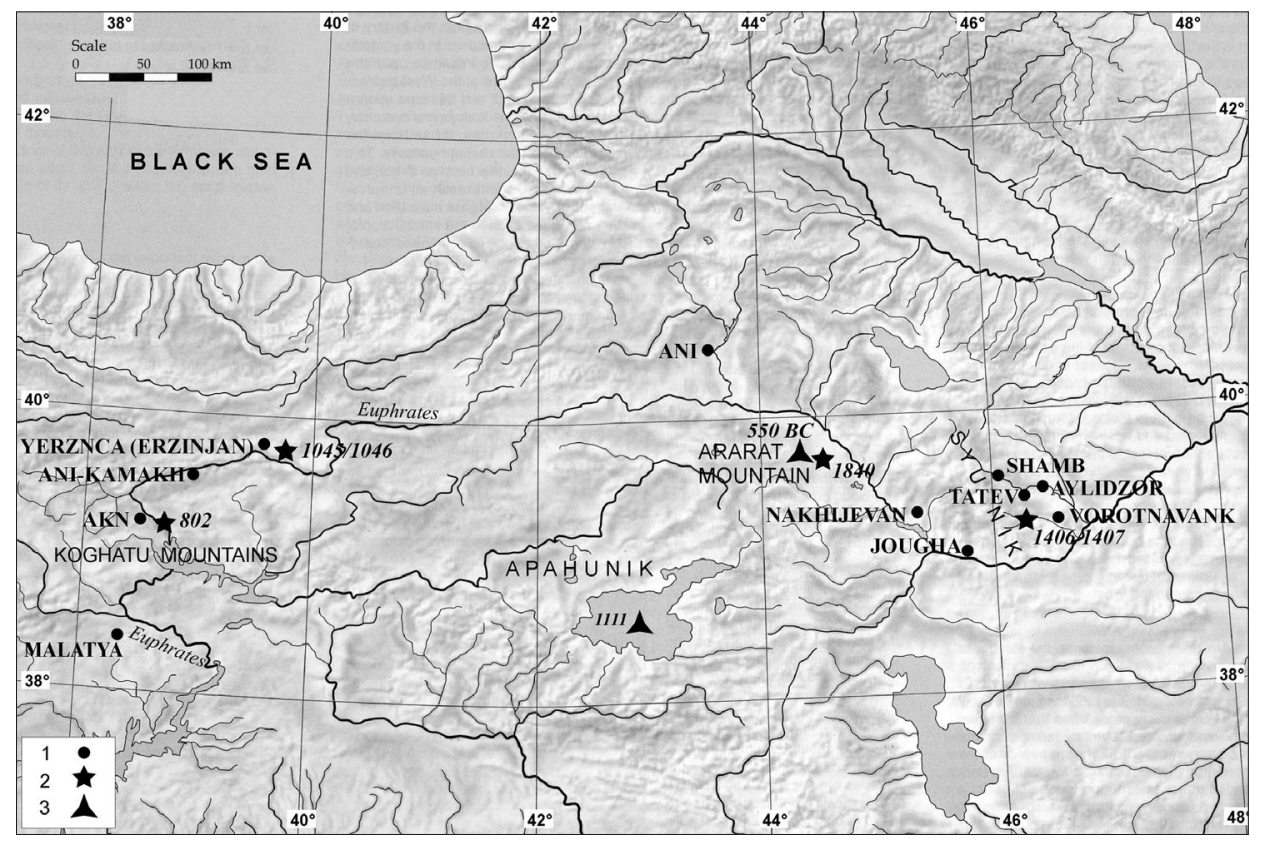

Fig. 2. The map of the Armenian Highland with indications of geographic place-names, historical earthquakes and volcanic eruptions discussed in the text: 1 - historical settlements and provinces; 2 - epicentres of historical earthquakes, for which new parameter estimates have been made as discussed in the text; 3 - historical volcanic eruptions. 
tre of the event in Mesopotamia and exclude this event from the catalogue of earthquakes in ancient Armenia. We know, however, that the Koghatu Mountains are situated in the upper riches of the Euphrates, $30 \mathrm{~km}$ to the southwest of the city of Erzinjan, near the towns of AniKamakh and Akn (see the next paragraph) (fig. 2 ). Therefore, it is early to exclude the considered earthquake from the list of historical Armenian earthquakes.

The catalogues of Kondorskaya and Shebalin (1977), Karapetian (1986, 1991), Papazachos and Papazachou (1997), NSSP (1998) and NOAA all mention two earthquakes with the date of 1045 (or 1046 in some catalogues), suggesting that one of them with a magnitude of $M=6.0-7.0$ destroyed Yerznca (Erzinjan), while the second event of $M=5.5$ struck the city of Ani, $350 \mathrm{~km}$ east of Yerznca. Our analysis of original chronicle sources shows that apart from Yerznca, destruction in 1045 was recorded not in Ani, but in the town of Ani-Kamakh (today's city of Kamakh in Eastern Turkey), $30 \mathrm{~km}$ to the southwest of Yerznca (fig. 2). Originally published in the Acts of the Caucasian Archeographic Commission Meeting (1873), this wrong location of the earthquake was repeated by other catalogues for 100 years onwards, and resulted in the duplication of the 1045 event.

Another example of errors related to ancient geographic names is illustrated in Appendix B. Such errors can be found in many earthquake catalogues. Six volumes of the Toponymic Dictionary of Armenia and Adjacent Areas by Hakobian et al. (1986-2003) may help researchers in locating Armenian place-names correctly. Useful information can be found also in the historical atlases of Cilicia (Mutafian, 1988) and in Armenia: A Historical Atlas, a fundamental work of Hewsen (2001).

Catalogues often misestimate earthquake parameters due to incomplete or imprecise translation from the Old Armenian language. Discussing information available for the Armenian earthquake of 1406 (or 1407 in some catalogues), Guidoboni et al. (1996) cite the original report from manuscript Matenadaran $9247 a$ and provide the following translation: «... Now let me tell the calamity of those who have doubts and of the grief of this country. Because of the quantity of our sins, the earthquake happened on the earth, and because of it the fundaments trembled and the stones quarried and the earth was trembling the whole year. And while this tributation the premature death reached the countries of Jula and Śamb».

Interpreting this account written in the Tatev Monastery, Guidoboni et al. (1996) conclude that it tells about a low-intensity earthquake in the Tatev monastery region (fig. 2). They also comment that the mention in this text of «premature death reaching the countries of Jula (Jougha) and Samb (Shamb)» shall not be related to the earthquake of 1406, but rather to the death of few monks in those regions.

Actually, the translation cited by Guidoboni et al. (1996) omits two phrases - one in the middle part of the passage, and one in its end. Below we present the passage in full, translated according to Zeitounian (1991), and emphasize the omitted parts in italics.

«Now let me tell the calamity that caused perturbation and grief in these places. Because of the quantity of our sins, the earthquake happened on the earth, the fundaments of the earth trembled and the firm natural stones crashed, and many corps of numerous dead were found, since the earth was trembling the whole year constantly. Before that time, we had banished anxiety out of our mind, and then premature death reached /the people/ in Jula and Šmb, and today Smbat's brother, Lord Broutel with his sons passed away in Christ, and also Smbat's son and many others that are countless. And who can describe the sorrowful cries and the yell of women who lost their children?».

The omitted part of the text allows us to suggest a strong earthquake with numerous victims, and to identify the area of greatest destruction it caused, since we know that Lord Broutel was not a monk, but the prince of Sunik. A gravestone inscription on his tomb in the Vorotnavank Monastery tells about his death and the death of his children and people of his suite in 1406. Death found them all in the Vorotnavank Monastery, on their way home from the funeral of some Ozbek, when the monastery was destroyed by a strong earthquake. A detailed account of the earthquake in 
1406 can be found in a verse by the poet Arakel Suniketsi, a contemporary of the event. Some phrases in his verse suggest that an epidemic and migration of the population followed the earthquake.

The Vorotnavank Monastery, reconstructed in 1438 , is situated $13 \mathrm{~km}$ to the east of the Tatev Monastery, $17 \mathrm{~km}$ to the southeast of Shamb, and $55 \mathrm{~km}$ to the north of Jougha (fig. 2).

The Tatev Monastery was also damaged severely. In his manuscript of 1411, chronicler Movses writes: «O venerable Fathers and brethren, I beg you to pray the Lord pleading Him to have mercy on us and restore anew what have been destroyed by the earthquake». The intensity of the earthquake is attested also by the following comment of Tovma Mekopetsi, a scribe from the Tatev Monastery: «Glory to Your Mercy and Grace, Jesus, my Lord, who saved us of this earthquake, since my house trembles like a leaf. $\mathrm{O}$, an astonishing earthquake that trembles the Tatev Monastery of Surb Arakelots, the belltower, and the Gavazan. It was on the 29th of November» (translation according to Zeitounian, 1991).

Actually, in the Tatev Monastery, the Gavazan was not a wooden or metal crosier, or staff used during liturgy, as commented in Guidoboni et al. (1996), but an 8m-high stone obelisk (fig. 3). This Gavazan obelisk was erected in 904 as an octahedral column of stones crowned with an ornamented cornice and kachkar stone stele. The Gavazan obelisk could serve to record seismic oscillations (Khalpakhchian, 1962, 1980). From seismic ground shaking, or even a strong strike with one's hand, this gavazan can tilt and return back to its original position like a pendulum thanks to the hinged connection of the column with the stylobate.

The 1931 earthquake with estimated intensity 9 in the area of the Tatev Monastery (MSK-64) destroyed its churches, and had macroseismic impacts on the «Gavazan» obelisk similar to those recorded in 1406 (Gorshkov, 1932, 1933; Karakhanian et al., 2003). Apart from destruction in the Tatev Monastery, the 1931 earthquake caused damage to the «Vorotnavank Monastery», and severe destruc-

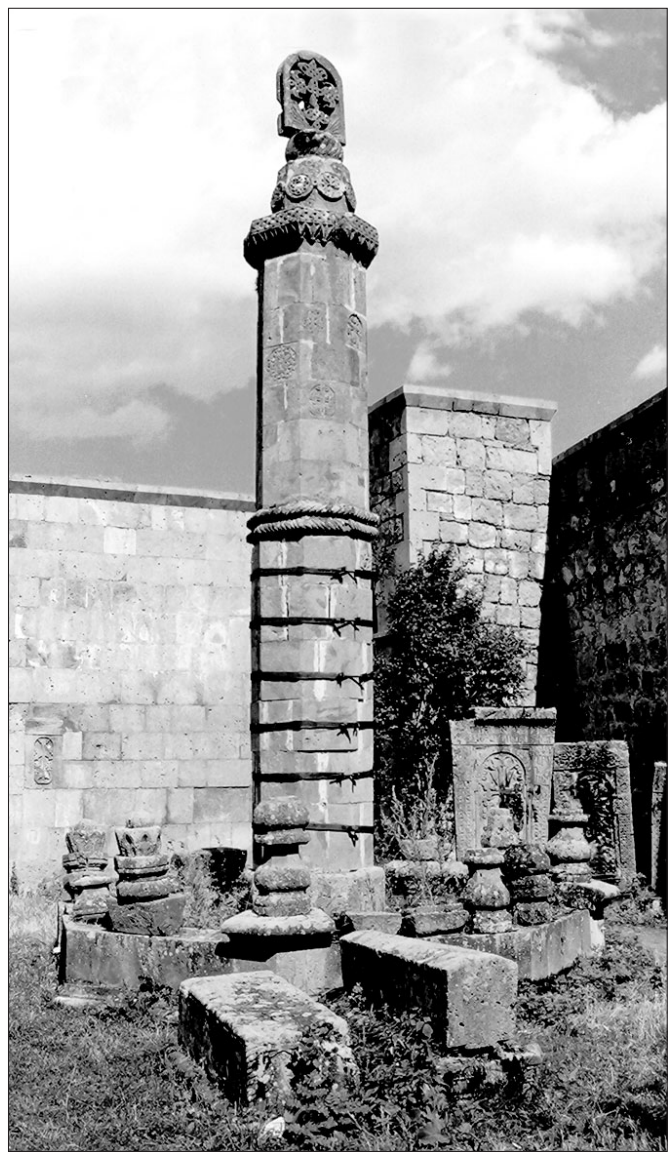

Fig. 3. Gavazan obelisk in the Tatev Monastery, situated in the south of today's Armenia (photo by A. Karakhanyan).

tion and casualties in Shamb and Jougha, for which intensity rates are estimated at 9 and 8 by MSK-64, respectively (Gorshkov, 1932, 1933; Karakhanian et al., 2003). Therefore, the macroseismic effects of the 1931 earthquake $(M=6.5)$ can be commensurable with the effects of the 1406 event.

Studying historical sources, earthquake catalogue authors often translate, analyze, and later use information from only one short passage from the text, which directly refers to an earthquake, while the rest of the text is dis- 
regarded. In the meantime, reading and analyzing of the whole text of the source is essential and can help to estimate earthquake parameters accurately (see examples in Appendices $\mathrm{A}$ and $\mathrm{B}$ ).

As illustrated by the example below, another typical error is misinterpretation as earthquakes of historical evidence attesting to other natural disasters. Beginning from the catalogue of Musketov and Orlov (1893), many recent catalogues (Stepanian, 1964; Kondorskaya and Shebalin, 1977; Karapetian, 1986, 1991; NSSP, 1998) have recorded intensity 6-7 events in 1658 and 1622 in an area near the village of Ailidzor (fig. 2) in the province of Sunik (south of Armenia). However, historical sources cited by Arakel Davrizhetsi and Zackaria Sarcavagi are dated to 1658 , and not 1622 , and clearly describe a landslide near the Ailidzor village, but not an earthquake. Therefore, these events should be unambiguously excluded from earthquake catalogues (Haroutunian et al., 1997)

Numerous descriptions of volcanic eruptions in Armenian manuscripts indicate that volcanic hazard and risk in this country are by no means lower than the hazard and risk of strong earthquakes (Karakhanian et al., 2002; Haroutunian, 2001). Matteos Uorkhaetsi, an Armenian chronicler of the 12th century, reports about the phenomena observed near Lake Van: «Severe destruction occurred the same year of 1111 in the mentioned area. In Armenia's province of Vaspourakan, in winter, the vault of heaven opened wide and fire poured down into Lake Van. Waves surged on the shore with a terrible noise. Waters and land trembled with horrible crash. Lake water turned red. The flame tore the solids of the abysses. In the morning, people saw that multitude of fish had died. A stench filled all around. Very deep clefts cut through the earth in many places».

Abich (1882), Stepanian (1964), Ergin et al. (1967), Karapetian (1986, 1991), NSSP (1998), and many other catalogues interpret this report as evidence of a strong earthquake. Guidoboni and Traina (1995) believe that was a landslide. We think the passage rather describes a volcanic eruption in the lake water area, than an earthquake, or a landslide (fig. 2).

\section{Discussion and conclusions}

The Armenian Highland and areas adjacent to it were densely populated throughout the historical period, and even in the pre-historical time. This was an arena of emergence, development and decline of many large cultures of the past.

Archaeological monuments for a period from the 5th millennium B.C. till the 18th century A.D., rock paintings of the 6th-3rd millennia B.C. (so called petroglyphs), folk epics and legends, cuneiform inscriptions of the Hittite and Urartian cultures (19th - 6th century B.C.), and antique and medieval chronicles (2nd-18th centuries A.D.) provide a huge amount of descriptions of natural calamities and their social impacts almost for the entire period of the Holocene.

One would think that such a long record of natural disasters in the Armenian Highland should facilitate seismic hazard assessment studies for this region, where historical seisimicity studies were started late in the 19th century. However, in Armenia of the 1960s-1980s these studies were not a priority, their findings were considered subjective and disregarded in seismic hazard assessment.

After the earthquakes of 1988-1991, 12 seismic catalogues compiled for the area of the Armenian Highland (table I) included much new evidence on historical earthquakes. In the meantime, even most complete parametric catalogues (Shebalin and Tatevossian, 1997; Berberian, 1997) often did not include new historical evidence collected in descriptive ones (Zeitounian, 1991; Guidoboni and Traina, 1995; Guidoboni et al., 1996). Moreover, there is certain confrontation between historians and seismologists, who, as a rule, are authors of descriptive and parametric catalogues, respectively. Historians consider that seismologists lack relevant competence for historical studies (Zeitounian, 1991), while seismologists avoid presenting original historical sources they have used to estimate earthquake parameters. Despite proponents of joint research in both camps (Guidoboni and Traina, 1995), there still has not been a successful attempt in this direction.

One common shortcoming of both descriptive, and parametric catalogues has been the ab- 
sence of information from archaeological and paleoseismological sources. The 1988 Spitak earthquake in Armenia and 1991 Racha earthquake in Georgia occurred in zones for which the catalogues had not recorded strong historical seismicity. The paleoseismic and archaeological studies conducted in the zone of Spitak earthquake indicate that recurrence interval of strong earthquakes in this region may range from 5000 to 17000 years (Philip et al., 1992, 2001, Karakhanian et al., 2003). While historical analysis is still applicable for a date of 5000 years ago, although with nearly extreme resolution of this method, historical record would appear too short to help in assessing seismic hazard in Armenia in case of an interval of 17000 years. Therefore, archaeoseismological and paleoseismological methods must be applied along with historical analysis. Paleoseismological evidence of strong earthquakes in the zones, for which no historical seismicity data had been available, were found for Georgia as well (Khromovskikh et al., 1979).

After 1997, historical seismicity studies in Armenia almost ceased due to the grave social and financial crisis started in the Southern Caucasian countries. Since 2001, we have attempted to create a new database on historical earthquakes, volcanic eruptions and other natural disasters in the Armenian Highland. The study has been conducted by an integrated group including historians, seismologists, geologists and archaeologists.

In coming years, jointly with our colleagues, we plan to prepare a new catalogue of strong earthquakes and volcanic eruptions in the Armenian Highland. This catalogue will contain detailed description of historical, archaeological, and paleoseismological sources attesting to the disasters of the past, as well as all principal parameters necessary to assess seismic and volcanic hazards.

\section{Acknowledgements}

The authors are grateful to Dr. Andranik Zeitounian from the Matenadaran Institute of Ancient Manuscripts, Dr. Vladimir Trifonov from the Institute of Geology of the Russian Academy of Sciences, Dr. Herve Philip from the Montpellier-II University (France), Dr. Massimiliano Stucchi (Italy), Dr. Ruben Jrbashyan and Dr. Ruben Haroutunian from the Institute of Geological Sciences of the National Academy of Sciences of Armenia, and also to Dr. Suren Arakelian, Dr. Haik Baghdassarian, and Dr. Ara Avagyan from the GEORISK Scientific Research Company. We would like to thank Vardan Makaryan from the Mother See of Holy Echmiatsin for arranging translations of texts from Old Armenian. We thank also Dr. Christine Chataigner (Maison de l'Orient Méditerranéen, Lyon, France), and Dr. Ashot Pilipossyan, Dr. Ruben Badalyan and Dr. Pavel Avetissyan from the Institute of Archaeology and Ethnography of the National Academy of Sciences of Armenia for their inestimable help and contribution to the realization of this work.

Appendix A. The Hittite and Armenian myths as potential sources of information about natural disasters of the ancient time

To date, there has not been an attempt to analyze old legends and myths and identify information they may contain about strong earthquakes, or natural calamities in Armenia and in neighboring countries. Nikonov (1991) just noticed briefly that the Armenian epic of Sassountsi David (David from Sassoun), or Sasna Tsrer, could contain reference to an old earthquake in Armenia. A more detailed analysis of Persian and some Armenian myths in relation to seismic and volcanic disasters belongs to Berberian (1994). We present here two examples demonstrating that ancient legends and traditions constitute one nearly untouched source of useful information about natural calamities of the past. 


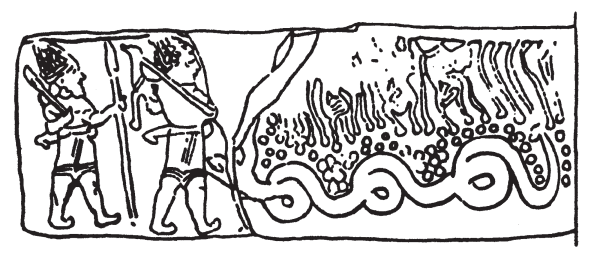

Fig. A.1. Bas-relief found in the city of Malatya, the southeastern Turkey: a god fighting a dragon (Gurney, 1966).

\section{A. 1. The Hittite Myth of the Slaying of the Dragon and the Myth of the Missing God}

During most of the 2nd millennium B.C., the ancient Hittite kingdom occupied the area of the Anatolian semi-island (fig. 1). One of the principal myths in the Hittite mythology is the myth of the fight between the dragon Illuyankas, living on a mountain, and the Weather-god (a prototype of Teishouba, the Urartian Thunderstorm-god) dated to the 16th-12th centuries B.C. In various versions of this myth, either the dragon, or the god wins this fight (Gurney, 1966).

A bas-relief picture found near Malatya (Eastern Anatolia, fig. 2) may depict a dragon fighting the Weather-god. Part of this picture resembles a lava-flow front: there are clear piles of burning stone blocks and tongues of flame behind anguine rings of the dragon's body (fig. A.1).

The second group of Hittite myths is related to a disaster that paralyzed all life on earth caused by the disappearance of the god of fertility. Gurney (1966) provides translation of a passage from the text of this myth that describes the disaster:

«Dust (?) clouds beset the window, smoke (?) besets the house, the embers on the hearth were choked (?), the gods stifled [in the temple], the sheep stifled in the fold, the oxen stifled in the stall, the ewe spurned her lamb, the cow spurned her calf. [...] Barley and emmer wheat throve no more, oxen, sheep and humans ceased to conceive, and those who were pregnant could not bear. Trees withered and the meadows and springs dried up. So there was a famine, and both gods and men began to starve».

The presented passage can be interpreted as a description of volcanic disaster effects, accompanied by emission of toxic gases, and of catastrophic environmental consequences and famine started as a result of the volcanic eruption.

The Ancient East History (1988) contains another translation of the same passage, where the word corresponding to «stifled» is interpreted rather as «squeezed», or «pressed down». By the second translation, we may imply that a strong earthquake accompanied the volcanic eruption in the 16th-12th centuries B.C.

The disaster could have stricken the eastern and central parts of Anatolia and reflected in the Myth of the Dragon Illuyankas and of his fight with the Weather-god. Other available evidence of historical eruptions in the region is dated to 6500 B.C. (Mellaart, 1967). Ferraud (1994) presents reports from Hurrian texts describing eruptions of a volcano near the city of Parsahanda, which made farming not possible during the life of one generation. According to Gurney (1966) and the Ancient East History (1988), the town of Parsahanda (Parsanda, or Bouroush'khatoun) was located on the southwestern spurs of the Taurus Ridge. We may assume that apart from domestic and external factors of military, political and economic character, environmental problems could also contribute have to the abrupt decline of the Hittite kingdom in the 11th century B.C.

A.2. Armenian legends and myths of the war of Tigran and Azhdahak and of the birth of Vahagn

Movses Khorenatsi, an Armenian historian and chronicler of the 5th century, provides the following report on an earthquake that caused landslip from the Ararat mountain slope in the 6th century B.C. 
«Tigran settled Anouish, the above-mentioned spouse (of Azhdahak) and her sons in a safe place: (remains of) the slide from the Great Mount said to happen from a terrible earthquake (start to) stretch from there. This is recounted by travellers who, by the order of Ptolemaeus, traveled long to measure in stadia not only the inhabited areas, but partly seas and uninhabited lands, from the torrid belt to the Cimmerion...»

Many scholars have analyzed this report to define the time and the place of the mentioned earthquake. Kovalevsky and Markov (1903), Kondorskaya and Shebalin (1977), Karapetian (1991), and Pirouzian et al., (1997) all record two earthquakes on Mount Ararat: one with the date of 550 B.C. and the other with the date of 139 A.D. (table I), although none of these authors presents any supporting arguments. Guidoboni and Traina (1995) believe that the above report of Movses Khorenatsi stems from the tradition in the Myth of Argonauts telling that Jason opened up a passage from the Arax River to the Caspian Sea (sources in Jessen and Tatevossian, 1916, col. 769) and therefore should not be regarded trustworthy evidence. Haroutunian et al., (1997), Shebalin, (1997) and Berberian (1997) record one earthquake only, suggesting that the earthquake mentioned by Khorenatsi should be related not to 550 B.C., but to 139 A.D.

In the discussed report, Movses Khorenatsi gives two indications of the time, and one indication of the place of the earthquake. We can with confidence identify the place of the earthquake as Mount Ararat, considering that since the time when Ararat was within the Ancient Armenia till today, Armenians have called Ararat the Great Mount. Other reports Khorenatsi presented in relation to the events of 550 B.C. also help to locate the event. Khorenatsi mentions that Tigran settled Azhdahak's spouse Anouish and many other captives «behind the eastern ridge of the Great Mount, up to the limits of Gokhtn, namely in Tambat, Oskiol, and Dazhagouik, as well as in the province of Vranjounik near the bank of the river (Arax), in front of the fortress of Nakhchavana» (p. 44, Movses Khorenatsi, 1893). Nakhchavana was an ancient Armenian town: today it is a city of Nakhichevan (Azerbaijan) in the Ararat Valley, near the Mount of Ararat (fig. 2). The areas listed by Khorenatsi are also located in the Ararat Valley.

So, the Great Mount is the Ararat volcano. By Khorenatsi's reference to the «(remains of) the slide from the Great Mount stretching from there» we can define the place where Anouish was settled more accurately, because the northern slope of Ararat, in the gorge of Akory, comprises deposits of huge debris flows triggered by strong earthquakes, the latest of which occurred in 1840 .

Definition of the date of this earthquake is a much more difficult task. Dragon Azhdahak in the Armenian mythology corresponds to the Iranian Azhi-Dakhaka (Dakhaka Dragon) and is equivalent to Astiag, the name of Mydian king (at rule since 585 till 550 B.C.), who was dethroned by Persian king Cyrus the 2nd (559-530 B.C.). According to the Armenian tradition cited by Khorenatsi, the Mydian kingdom and the king Astiag (Azhdahak) were defeated by Cyrus the 2nd and his ally, Armenian king Tigran the 1st Yervandian in 550 B.C. In his Cyropedia, Greek historian Xenophon (6th-5th century B.C.) confirms this relation, telling that Cyrus and the Armenian king Tigran were friends and allies in the military campaigns of Cyrus (Emin, 1893; Sarkissyan, 1990). Ptolemaeus Claudius worked in Alexandria in 127-151 A.D. and died in 168 A.D. Therefore, the two indications of earthquake date in the citation from Movses Khorenatsi are separated by a period of almost 700 years:

- Anouish, Azhdahak's spouse, was settled at the edge of the slide approximately in 550 B.C.

- The travellers sent by Ptolemaeus Claudius could visit Armenia between 127 and 151 A.D., i.e., within the period of Ptolemaeus' activities.

Studies of an earthquake in 550 B.C. and/or 139 A.D. have been limited to the analysis of the passage from the text of Khorenatsi presented above. Our analysis of the whole text, including the story of Tigran's victory over king Azhdahak in Khorenatsi's History of Armenia, allows new interpretation of this information.

Immediately next to the description of the place where Azhdahak's spouse was settled, Khorenatsi mentions legends about dragons living on the slopes of Azatn Massis (an Armenian name of Ararat) (p. 45, Movses Khorenatsi, 1893). Then Khorenatsi tells that before his battle with Tigran, Azhdahak had a dream of himself standing beside a high mountain with a snow-covered summit in the land of Haikides (Armenians). In his dream, Azhdahak saw a purple-dressed woman standing on the summit and giving birth to three sons. One of her sons, riding a lion, rushed to the sunset, the other son on a leopard went 
to the midnight, and the third one on a huge dragon pounced upon Azhdahak and his country, destroying them and shedding a sea of blood (p. 40, Movses Khorenatsi, 1893).

The legend of the birth of three sons to Tigran the 1st Yervandian, Azhdahak's winner, is of particular interest. According to this legend, Vahagn, the third son, was an old Armenian dragon-fighter divinity. The legend about Vahagn's birth reads:

«The Earth and the Heaven were in travail;

And the purple sea was in travail;

The sea gave birth to a reddish reed;

Smoke was coming out of the neck of the reed;

Flame was coming out of the neck of the reed;

A young man was coming out of the flame -

Fire was his hair;

Flame was his beard,

And his eyes were /as two/ suns.»

The legend about the prophetic dream of Azhdahak is almost identical to the one of the birth of three sons to Tigran the 1st. In poetical manner, both legends link the third son to a dragon he defeats. In the Armenian folklore, the name of Azhdahak is usually identified with a dragon. Many ancient Asian legends refer to volcanic lava flows, or earthquake-triggered landslides, as to dragons (Khromovskikh, 1984; Ferraud, 1994).

For instance, the ancient Iranian epic Shahnameh of Ferdausi-Tusi tells how Khrouden (Feridoun), a legal successor to the throne, dethrones the evil king Zohak (a dragon-equivalent name) and imprisons him shackled in a deep sulfuric pit (crater) of the active Damavand volcano in Northern Iran (Sarkissian, 1990; Berberian, 1994).

A direct identification of the Azhdahak dragon, confined in a mountain, with the eruption of Sipan volcano (displaying solfataric activity recently) can be found in a manuscript of Muslim traveller Eulia Chelebi dated to the Middle Ages (Haroutunian, 2001):

«In the north of Lake Van, the seven-headed dragon Azhdahak is confined in the interior of Mount Sipan and his voice is heard once each 40-50 years, and for 5-10 days each 70 - 80 years he shows his tail from the Mount Sipan».

The principal sanctuary of Vahagn divinity has been located near Lake Van (Turkey), on the Mount of Nemrout, which is also an active volcano. Berberian (1994) considers the epic of Vahagn as an argument to suggest possible volcanic eruption in Armenia.

The discussed legends provide consistent poetical descriptions of an event that could be an earthquake (the Earth and the Heaven in travail), volcanic eruption of lava, or pyroclastic flow (red reed with flame and smoke rising out of it, etc.) or lahar-like landslide (a dragon rushing down, dragons living on Ararat) taking place on Ararat. In the meantime, these legends indirectly support a historical tradition about an earthquake and slide from Ararat mentioned by Khorenatsi in his report about the place where Azhdahak's spouse Anouish was settled.

The legends of the birth of Vahagn, Azhdahak's dream, and captivity of Artavazd were for the first time collected and recorded by Khorenatsi in the 5th century A.D. Cited only by Khorenatsi, the Vahagn's birth legend can be older than the events Khorenatsi related to 550 B.C. (Petrosyan, 2002). Although apart from the information provided by Khorenatsi in relation to the names of Azhdahak, Tigran and Ptolemaeus, we have no other data to define when and where these legends and traditions of an earthquake or volcanic eruption were created, it is important to consider that Tigran the 1st Yervandian and Azhdahak (Astiag Mydian) are all historical personages of the first half of the 6th century B.C.

Considering the traditions and legends cited by Khorenatsi, we might with certain caution suggest that they refer to real events - earthquake, volcanic eruption, and lahar-landslide, all occurring on Ararat during the opposition between Tigran and Azhdahak in the first half of the 6th century B.C. (about 550 B.C.). Historical, archaeological and geological data attest to a few historical eruptions of the Ararat Volcano (Karakhanian et al., 2002). The latest happened in 1840 and was triggered by a 
very strong $M=7.4$ earthquake (Ambraseys and Melville, 1982). The earthquake was accompanied by volcanic eruption and large lahar-type landslide in the Akory gorge. The frontal part of sediments in the gorge is about the place, where, according to the legend, Azhdahak's spouse Anouish could be settled (Karakhanian et al., 2002). The first part of the Khorenatsìs report directly links the earthquake and the slide with the names of Tigran, Azhdahak, and his wife Anouish, i.e., with historical personages of the first half of the 6th century B.C. (about 550 B.C.). The second part of the Khorenatsìs report, however, does not contain any indication that the earthquake described by the travelers sent by Ptolemaeus happened the time they visited Armenia (between 127 and 151 A.D.). Therefore, there are no serious grounds to assume that the earthquake reported by Khorenatsi occurred not in 550 B.C., but rather in the 2nd century A.D. (between 127-151 B.C.) as earlier suggested by Haroutunian et al. (1997) and Shebalin and Tatevossian (1997). Nevertheless, the case of two separate events, although much less supported by Khorenatsi's reports, shall not be ruled out completely.

Appendix B. The earthquake of July 25, 454 A.D. in Eastern Iran, near the town of Nishapur (the land of Apar, town of Nishapoukh).

«The same day (the 27th day of the month of hrotic' - the 25th of July) in the evening, a strong earthquake suddenly happened in this place. A thunder-like noise and terrible voices were heard from the depth, masses of gathered clouds covered the earth; thundering and lightning shook the mountains. A column of light descended to the ground as a rainbow and wrapped around the bodies of martyrs. The guard was thrown down to the ground half-alive, no one knowing where his neighbor was: they went round and could not stand on their feet firmly, because the shaking caused by the strong earthquake was throwing them up and down to the ground» (Lazar Parpetsi, 1904).

Guidoboni and Traina (1995) consider the above account of the Armenian historian Lazar Parpetsi, who lived in late 5th-early 6th century A.D., in the context of historical seismicity. The historian includes his report to the story about the martyrdom of Saint «Associates of Ghevond», who were Armenian grandees and monks captured by Persian king Shapouh during the war of 450-453 A.D. After the captive Armenian priests and princes refused to adopt Zoroastrism, they were taken to the land of Apar in the northeast of Iran and kept in prison in the region of the town Nishapouh (Nishapur). Later, some of them were killed, and some died in exile. By the time the earthquake happened, Persian warders had guarded the captives. Lazar Parpetsi also adds that «the shaking continued one day and two nights».

Analyzing the report of Lazar Parpetsi, Guidoboni and Traina (1995) assume a link between the earthquake of 454 and the accounts about an earthquake in 461 in the locality of Apahunik, contained in 13th century A.D. Chronicles of Hovhannes Avageratsi (1951): «There was an earthquake at Apahunik, and it destroyed many villages».

Assuming that the historians could confuse similar place-names of Apar (Lazar Parpetsi) and Apahunik (Hovhannes Avagheratsi), Guidoboni and Traina (1995) suggest that there could be a single earthquake. Although with some reservations, Guidoboni and Traina (1995) identify the earthquake of 454 in Apar with the earthquake in Apahunik in 461 and include the latter in their earthquake catalogue. The province of Apahunik was located to the west of Lake Van, in the middle course of the Aratsani (Mourat) River (figs. 2 and B.1). As this area was familiar to all Armenian historians, it is difficult to suggest that they could confuse it with the land of Apar, also a well-known locality in the east of Iran (fig. B.1), close to the Lut desert boundary. Yeghishe, an Armenian historian of the 5th century A.D., contemporary and eyewitness of the rebellion of Armenians against Persians in 451, adds information in support of locating the July 25 earthquake of 


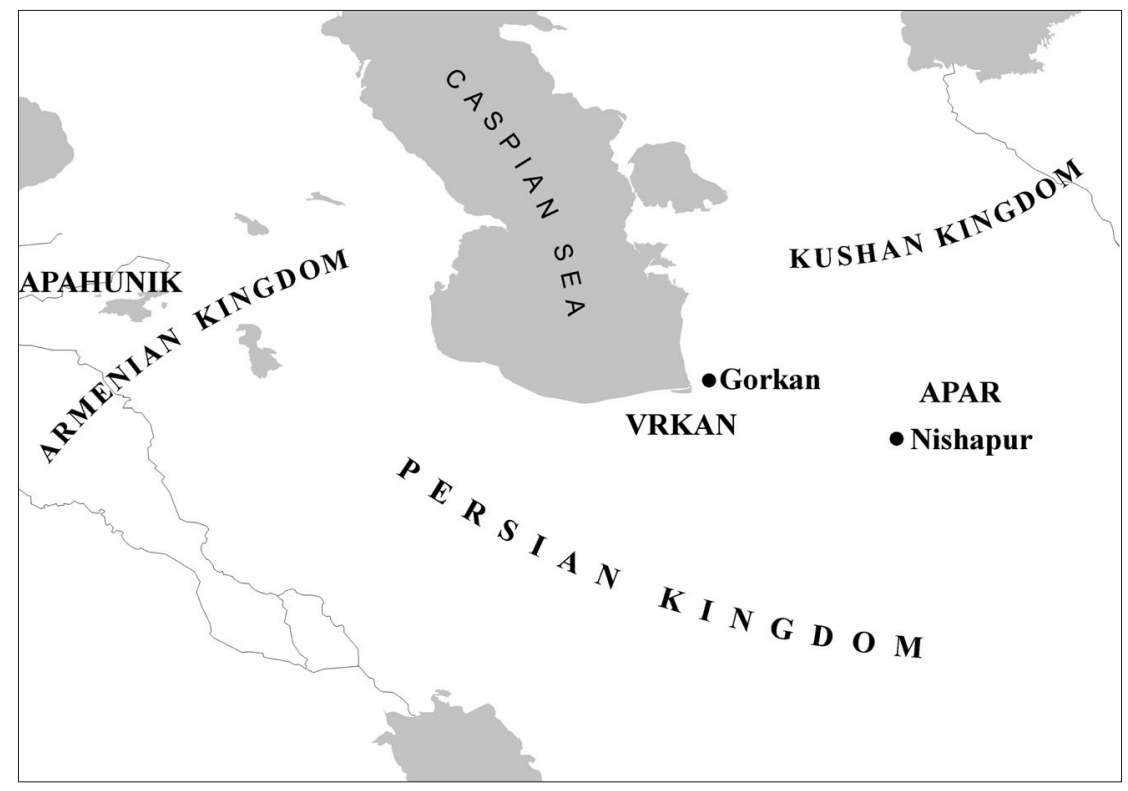

Fig. B.1. Historical geographical place-names related to the earthquake of 454 A.D.

454 in the vicinity of Nishapur in the land of Apar, according to Lazar Parpetsi. Yeghishe (1971) wrote: «By the midnight, horrible sounds were heard again, and thunder-like rolls (that reached us) from beneath resembled earthquake rumble, the earth trembled under their feet, and sparkles from the glare of swords were flying around them».

Guidoboni and Traina (1995) notice that Yeghishe did not mention the place of the earthquake of 454, but we believe he actually did. In Chapter 7 of his History of Armenia, Yeghishe clearly indicates the place, where Armenian princes and six captive priests were kept guarded: «So, in the sixteenth year of the rule of the same king, he (the king) again went to the land of Koushans for martial affairs. Coming out of Vrkan and entering the land of Apar, he ordered to hold the nakharars /princes/ and priests in the same bonds - in the citadel of the town of Nishapouh» (verse 142, p. 127, Yeghishe, 1971).

The king mentioned in the account was Yezdegerd the 2nd Sassanid, who reigned since 438 till 457 A.D. Therefore, the sixteenth year of his rule corresponds to 454 A.D., which confirms the date of the earthquake. The land of Koushans corresponds to the Koushan Kingdom (1st century B.C.-5th century A.D.), which covered the greater part of the Middle Asia, Northern Afghanistan, and Northern India. In the 4th-5th centuries A.D., the Sassanid Iran led constant wars with Koushanians. Vrkan was an area to the southeast of the Caspian Sea (nowadays Torkan, a city in Iran). The land of Apar covered an area in the northeast of Iran: later it was named Khorassan and Nishapouh was its principal city. Today, Nishapouh corresponds to the city of Nishapur in the northeast of Iran, on the border of the Lut desert. Then Yeghishe mentions: «Having arrived at the (designated) deserted place, which appeared totally devoid of green vegetation and so wild and stony, that the three nakharars (princes) could not find a place even to take a seat ...» (verse 160, p. 141, Yeghishe, 1971).

«And these six died a saint and desired death on the 25th day of the month of hrotic' (July), in the great desert of the land of Apar near the town of Nishapouh (Nishapur)» (verse 182, p. 158, Yeghishe, 1971). 
The place of the earthquake was repeatedly and clearly described by the historian Yeghishe, who was contemporary to the events. Besides, the full-flow river Aratsani (Mourat) and numerous springs in the mountainous landscape of the province of Apahunik could hardly be confused with the description of the Lut desert we read in Yeghishe's account. Therefore, there are no grounds to suggest that the earthquake of 454 A.D. reported by Parpetsi and Yeghishe, the 5th century historians, and the earthquake of 461 A.D. reported by Avageratsi, the 13th century historian, should be related to the single seismic event in 461 that happened at Apahunik, west of Lake Van. The earthquake of July 25 in 454 occurred in the east of Iran, in the region of the city of Nishapur, most probably within the zone of the Nishapur-Binaloudi active fault.

\section{REFERENCES}

AвICH, G. (1862a): Distribution Map for the Ararat earthquake, Notes of the Caucasian Division of the Russian Imperial Geographic Society, Tbilissi, vol. 5.

AвICH, G. (1862b): Earthquakes in Shemakha and Erzroum of May 1859, Notes of the Caucasian Division of the Russian Imperial Geographic Society, Tbilissi, vol. 5.

АвICH, G. (1882): Geologie des Armenischen Hohlandes Westhalfte, Geologische Forschungen in den Kaukasichen Ländern, Wien, 479.

Acts of the Caucasian Archeographic Commission Meeting (1873), in Archive of the Caucasus Governor's Principal Administration, Tbilissi, vol. 5.

Alishan, G. (1881): Shirak, Venice.

Alishan, G. (1890): Airarat, Venice.

AmbraseYs, N.N. (1975): Studies in historical seismicity and tectonics, Geodynamics Today (Royal Soc. Publ., London), 7-16.

Ambraseys, N.N. (1988): Engineering Seismology, Earthquake Eng. Struct. Dyn, 17, 1-105.

Ambraseys, N.N. and R. AdAms (1989): Long-term seismicity of North Armenia, EOS, Trans. Am. Geophys. Un., 70, 145-154.

AMBRASEYS, N.N. and J.A. JACKSON (1998): Faulting associated with historical and recent earthquakes in the Eastern Mediterranean region, Geophys. J. Int. 133 (2), 390-406.

Ambraseys, N.N. and C.P. Melville (1982): A history of Persian Earthquakes (Cambridge University Press, Cambridge), pp. 219.

Ancient East History (1988): The Ancient East History: Origin of the earliest class societies and the early sources of slave-owning system civilizations, 2. Front Asia, Egypt, edited by G.M. Bongard-Levina (Principal Editorial Board of Oriental Literature, Moscow), 619 (in Russian).

ARMENIE (1996): Tresors de l'Armenie ancienne (des origines au IVe siecle) sous la direction de Jacques Santrot, Paris, pp. 288.

Avagyan, A., A. Karakhanian and H. Philip (2003): Une éruption volcanique gravée dans le roc, Pour la Science, 305, 13-14.

BERBERIAN, M. (1994): Natural hazards and the first catalogue of Iran. Historical Hazards in Iran Prior to 1900, Int. Inst. Earthquake Eng. Seismol., 1, 603.

Berberian, M. (1997): Seismic sources of the Trans-Caucasian historical earthquakes, in Historical and Prehis- torical Earthquakes in the Caucasus, edited by D. GIARDINI and S. BALASSANIAN, ILP Publ. 333, NATO ASI Ser. 28 (Kluwer Academic Publishers), 233-311.

BOMmER, J.J. and N.N. AMBRASEYS, (1989): The Spitak (Armenia, USSR) Earthquake of 7 December, 1988: a preliminary engineering seismology report, ESEE/EFTU Research Rep. 89/1, Eng. Seismol., 85.

Borissov, B.A. (1982): About the importance of evidence of past earthquakes for seismic hazard assessment in the Greater Caucasus, Bull. MOIP, Geol. Sec., 57, 1.

BorisSOv, B.A., G.I. REISNER and V.I. SHOLPO (1975): Identification of Earthquake-Prone Zones in the Alpine Folding Area (Publishing House Nauka, Moscow), p. 138.

Byus, E.N. (1948): Seismic conditions in the Trans-Caucasus. Part I: Chronology of Earthquakes in the TransCaucasus, Tbilissi (in Russian).

Chronicle of Amiras Yerzncatsi (1988): Chronicle of Amiras Yerzncatsi, 17th century, Historical Journal of the Armenian Academy of Sciences, Yerevan, 4, 189-208.

Dewey, J.F., M.R. HeMPTON, W.S.F. KIDD, F. SAROGLU and A.M.C. SENGOR (1986): Shortening of continental lithosphere: the neotectonics of Eastern Anatolia - a young collision zone, in Collision Tectonics, edited by M.P Coward and A.C. RIEA, Geol. Soc. London, Spec. Publ. 19, 3-36.

EMIN, N.O. (1893): Comments to the History of Armenia edited by Movses KHORENATSI (Lazarev's Institute of Oriental Languages, Moscow), 412 (in Russian).

ERgIN, K.U., U. GuCLU and Z. Uz (1967): A Catalogue of Earthquakes for Turkey and Surrounding Area (11 A.D. to 1964 A.D.), Istanbul.

FERrAUD, J. (1994): Les volcans actifs de Turquie: guide geologique et itineraries d'excursions, Memoire de l'Association Volcanologique Européenne, 2, 140 (in French).

GorshKov, G.P. (1932): The Zanghezour seismic expedition, in The Volume on the Zanghezour Seismic Expedition, edited by N.V. RAIKO, Vestn. Akad Nauk SSSR, (special issue of the USSR AS Expedition of 1931, Leningrad) (in Russian).

Gorshrov, G.P. (1933): Geological Settings of the Zanghezour Earthquake of April 27, 1931, Tr. Seismol. Instit. Akad Nauk SSSR, Moscow-Leningrad, 31 (in Russian).

Guidoboni, E. and G. Traina (1995): A new catalogue of earthquakes in the historical Armenian area from antiquity to the 12th century, Ann. Geofis., XXXVIII (1), 85-147. 
Guidoboni, E. et al. (1996): Catalogue of the Earthquakes in Armenia for 13th-18th century (SGA, Bologna), pp. 67.

Guidoboni, E., R. Haroutunian and A. KarakHANiAN (2003): The large earthquake in Garni (Armenia) on 14 June 1679: a re-analysis, J. Seismol., 7 (3), 301-328.

Gurney, O.R (1966): The Hittites (Penguin Books Ltd. England), p. 240.

Hakobian, T.Kh., St.T. Melik-Bakhshian and H.KH. BARSEGHIAN (1986-2003): Hayastani ev harakits tehanunneri bararan, Toponimic Dictionary of Armenia and Adjacent regions (Yerevan University, Yerevan), 5 vols.

Haroutunian, R.A. (2001): About active volcanism in the Armenian Highlands, Izv. Nac. Akad. Nauk Armenii, Nauki o Zemlie, LIV (1), 1-12.

Haroutunian, R. and A.S. Karakhanian (1997): Seismic hazard in the area of the Yerevan city according to the historical seismicity data, in Natural Disasters Threatening the City of Yerevan (Emergency Administration of Armenia, Yerevan), pp. 20-29.

Haroutunian, R.A., A.S. Karakhanian and A.O. AssaTRIAN (1993): Unknown historical earthquakes of the Armenian Upland, in Abstracts Int. Conf. on Continental Collision Zone Earthquakes and Earthquake Hazard Reduction, Yerevan, 35-36.

Haroutunian, R.A., A.S. Karakhanian and A.N. AssaTRIAN (1997): Strong historical earthquakes in the Armenian Upland: new data and elaboration of a technique, in Historical and Prehistorical Earthquakes in the Caucasus, edited by D. GIARDINI and S. BALASSANIAN, ILP Publ. 333, NATO ASI Ser. 28 (Kluwer Academic Publishers), 375-382.

Hewsen, R.H. (2001): Armenia: a Historical Atlas (The University of Chicago Press Ltd. London), pp. 341.

Hovhannes Avagheratsi (1951): Chronicles Minor of the 13th-18th Centuries, prepared by V. HAKOPIAN (Publishing House of the USSR Academy of Sciences, Yerevan), vol. 2, 416

JACKSON, J. (1992): Partitioning of strike-slip and convergent motion between Eurasia and Arabia in Eastern Turkey and the Caucasus, J. Geophys. Res., 97 (B9), $12,471-12,479$

JACKSON, J.A. and N.N. AmbraseYs (1997): Convergence between Eurasia and Arabia in Eastern Turkey and the Caucasus, in Historical and Prehistorical Earthquakes in the Caucasus, edited by D. GIARDINI and S. BALAS SANIAN, ILP Publ. 333, NATO ASI Ser. 28 (Kluwer Academic Publishers), 79-90.

JACKson, J. and D.P. McKenzIE (1988): The relationship between plate motions and seismic moment tensors, and the rates of active deformation in the Mediterranean and Middle East, Geophys. J., 93, 45-73.

INČIČEAN, L. (1822): Description of Ancient Armenia, Venice, 3 vols.

INČIČEAN, L. (1835): Geographical Antiquities of the Land of Armenia, Venice, 3 vols.

Karakhanian, A.S., R.T. DJRbashyan, V.G. Trifonov, H. PHILIP and J.F. RITZ (1997): Active faults and strong earthquakes of the Armenian Upland, in Historical and Prehistorical earthquakes in the Caucasus, edited by D. GiaRdinI and S. BALASSANIAN, ILP Publ. 333, NATO ASI Ser. 28 (Kluwer Academic Publishers), 181-187

Karakhanian, A., R. Djrbashian, V. Trifonov, H. Philip, S. ARAKELIAN and A. AVAGIAN (2002): Holocene-his- torical volcanism and active faults as natural risk factor for Armenia and Adjacent Countries, J. Volcanol. Geotherm. Res., 113 (1-2), 319-344.

Karakhanian, A., A. Arakelian, S. Mouradian, V. Trifonov, A. Avagyan, V. Balassanian, H. Bagdassarian, S. Arakelian, V. Davtian, Y. Abgarian and A. MELIKIAN (2003): Seismic hazard assessment for the Ghekhi Dam, Armenia, Report, Georisk CJS Co., Yerevan, p. 90.

Karakhanian, A. V. Trifonov, H Philip, A. Avagyan, K. Hessami, F. Jamali, S. Bayraktutan, H. BagdassariAN, S. Arakelian and V. DAvtian (2004): Active faulting and natural hazards in Armenia, Eastern Turkey and North-Western Iran, Tectonophysics (in press).

KARAPETIAN, N.K. (1986): Earthquake Origin Mechanism in the Armenian Highland (Publishing House of the ArmSSR Academy of Sciences, Yerevan), 227 (in Russian).

Karapetian, N.K. (1991): Earthquakes of the Armenian Highlands (Seismic Setting), (Los Angeles CA).

KHALPAKHCHIAN, O.KH. (1980): Architectural Ensembles of Armenia (8th century B.C-19th century A.D.), (Iskustvo Publishers, Moscow), 479 (in Russian).

KHALPAKHCHIAN, O.KH. (1962): The oscillating column in Tatev, Echmiatsin, 9, 12-18 (in Russian).

Khanlaryan, L. (1983): New Chronology Dedicated to Earthquakes (Lraber hasarakakan gitutiunneri, Yerevan), 10, 65-67 (in Armenian).

Khromovskikh, V.S. (1984): A Stone Dragon (Misl, Moscow), pp. 155 (in Russian).

KHROMOVSKIKH, V.S., V.A. SOLONENKo et al. (1979): Paleoseismology in the Greater Caucasus (Nauka, Moscow), pp. 182 (in Russian).

KondORSKAYA, N.V. and N.V. SHEBALIN (Editors) (1977): New Catalog of Large Earthquakes in the USSR Area (Nauka Publishing House, Moscow), pp. 536 (in Russian).

Kostaneanc, K. (1902): Sharzhi taregrutiun Hayots mej, Yearbook of earthquakes in Armenia, Tbilissi (in Armenian).

Kovalevsky, E.R. and E.C. Markov (1903): On the Ararat Mountains, Tbilissi, 156 (in Russian).

LAZAR PARPETSI (Editor) (1904): The History of Armenia by Lazar Parpetsi and his message to Vardan Mamikonian, prepared by G. TER-MKRTCHIAN and ST. Malkhasian, Tbilissi (in Armenian).

LEBEDEV, P. (1931): Earthquake in Armenia in connection with seismicity and structure of the Middle East, Vestn. Znaniya, Leningrad B (in Russian).

MellaArt, J. (1967): Catal Huyuk, a Neolithic Town in Anatolia (Thames and Hudson, London), p. 176.

Moinfar, A., A. Mahdavian and E. MaleKi (1994): Historical and Instrumental Earthquakes Data Collection of Iran (Iranian Cultural Affairs Institute), p. 445.

MOVSES KHORENATSI (1893): History of Armenia (Lazarev's Institute of Oriental Languages, Moscow), 412, (translated by N.O. EMIN)

Musketov, I.V. and A. Orlov (1893): Catalogue of Earthquakes in the Russian Empire, Notes of Russian Geol. Soc., St. Petersburg, 26 (in Russian).

Mutafian, C. (1988): La Cilicie au Carrefour des Empires, Collection d'Etudes Anciennes (Société d'edition Le Belles Lettres), vol. 2, pp. 431.

NiKonov, A.A. (1991): Destructive historical earthquakes 
in Soviet Armenia, Tectonophysics, 193, 225-229.

NSSP (1998): The NSSP Catalogue of Earthquakes ( $M \geq$ $\geq 5.5)$ in the Territory of the Republic of Armenia and Adjacent Regions, Yerevan.

PAPAZACHOS, B. and C. PAPAZACHOU (1997): The Earthquakes of Greece (P. Ziti and Co., Thessaloniki, Greece).

Petrosyan, A. (2002): The Armenian Epic and Mythology: the Origin, Myth and History (Publishing house of the National Academy of Sciences of Armenia), 239.

Philip, H. and A. KarakHANian (1999): Tremblements de terre et archeologie, Pour la Science (Scientific American), 261 (July), 36-40.

Philip, H., E. Rogozhin, A. Cisternas, J.C. Bousguet, A BORISOV and A.S. KARAKHANIAN (1992): The Armenian earthquake of 1988 December 7: faulting and folding, neotectonics and paleoseismicity, Geophys. J. Int., 110, 141-158.

Philip, H., A. Avagyan, A. Karakhanian, J-F. Ritz and S. REBAI (2001): Slip rates and recurrence intervals of strong earthquakes along the Pambak-Sevan-Sunik Fault (Armenia), Tectonophysics, 343, (3-4), 205-232.

PIROUZIAN, S.A. (1972): Detailed study of seismic activity and seismotectonics of the Greater Yerevan region, $\mathrm{Ge}$ ology of the Armenian SSR, 10. Geophysics (Publishing House of the AS Arm SSR), (in Russian).

Pirouzian, S.A., S.Y. Balassanian, A.S. Avanessian, A.H. Martirosyan, A.R. Arakelian, A.L. Eloyan, H.A. Harutiunian, A.S. Matevossian and A.H. KaZARossian (1997): The catalogue of strong earthquakes in the territory of Armenia and adjacent regions, in Historical and Prehistorical earthquakes in the Caucasus, edited by D. GiARDINI and S. BALASSANIAN, ILP Publ. 333, NATO ASI Ser. 28 (Kluwer Academic Publishers), 313-331.
SARKISSIAN, G. (1990): Comments to the History of Armenia by Movses Khorenatsi (Publishing House Hayastan, Yerevan), pp. 291 (in Russian).

Shahatounianc', O. (1842): Description of the Echmiatsin Cathedral and Churches in Five Areas of Ararat, Echmiatsin, vol. II, pp. 380.

Shebalin, N.V. and R.E. Tatevossian (1997): Catalogue of large historical earthquakes of the Caucasus, in Historical and Prehistorical Earthquakes in the Caucasus, edited by D. Giardini and S. BALASSANIAN, ILP Publication 333, NATO ASI Ser. 28 (Kluwer Academic Publishers), 201-232.

Soysal, H., U.S. SiPahioglu, D. KolcaK and Y. Altdiok (1997): Turklye ve cevbesimi tabihsel depbim katalogu. Tuklye biumsel ve teknik arastirma kurumu matematik-fiziki ve biolojik bilimler arastieka grubu, Projeko TMG341, p. 32

StePANIAN, V.A. (1942): Brief chronology of the most important earthquakes in the historical Armenia and adjacent regions, in Proceedings of the Trans-Caucasian Conference on Earthquake Engineering, Yerevan, p. 36 (in Russian).

StePAnIAN, V.A. (1964): The Earthquakes in the Armenan Upland and the Surrounding Region, Yerevan, Hayastan, pp. 342 (in Armenian).

TAYmaZ, T., H. EyidOGAN and J. JACKSON (1991): Source parameters of large earthquakes in the East-Anatolian fault zone (Turkey), Geophys. J. Int., 106, 537-550.

YEGHISHE (1971): About Vartan and the Armenian War (translated from old Armenian by I.A. ORBELI), Yerevan (in Russian).

Zeitounian, A.S. (1991): Earthquakes in Armenia and neighbour countries (historical evidence from the ancient time till today), p. 383 (in Russian). 